\title{
Analisis Kandungan Biodiesel Hasil Reaksi Transesterifikasi Minyak Jelantah Berdasarkan Perbedaan Kosentrasi Katalis $\mathrm{NaOH}$ Menggunakan GC-MS
}

\author{
Amirul Mukminin ${ }^{1 *}$, Eka Megawat ${ }^{1}$, I Ketut Warsa ${ }^{1}$, Yuniarti ${ }^{1}$, Wildan Azizul \\ Umaro $^{1}$, Dian Islamiati ${ }^{1}$ \\ 1STT Migas Balikpapan, Indonesia
}

"Korespondensi: amirmin25@gmail.com

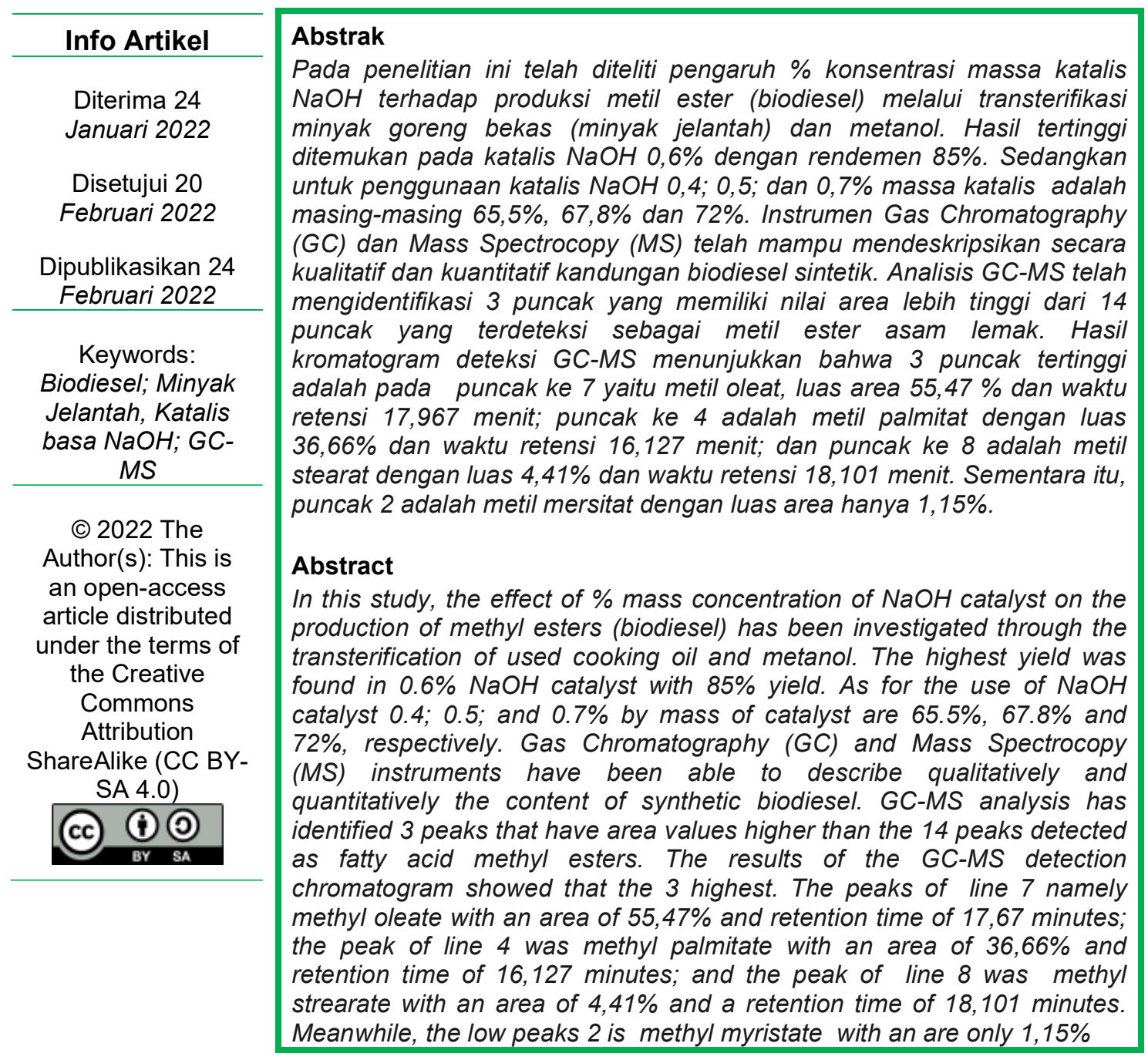




\section{Pendahuluan}

Minyak jelantah (minyak goreng bekas) telah banyak dilaporkan sebagai bahan baku biodiesel dan mempunyai kandungan asam lemak (Free Fatty Acid, FFA) yang tinggi hingga $5-30 \%$ b/b atau 3-40\% b/b (Ma \& Hanna, 1999; Maghami et al., 2015). Jenis asam lemak bebas (FFA) dalam minyak jelantah diantaranya adalah berupa asam laurik, asam miristat, asam palmitat, asam palmitoleat, asam stearat dan asam oleat. Kandungan FFA sangat menentukan jenis tahapan reaksi pembentukan biodiesel baik berupa reaksi transesterifikasi maupun reaksi eksterifikasi. Minyak goreng bekas lebih kental dibandingkan dengan minyak segar disebabkan oleh terbentuknya asam lemak jenuh pada saat terjadinya proses penggorengan (Ma \& Hanna, 1999), (Greever, 1995).

Pengaruh kosentrasi \% massa katalis $\mathrm{NaOH}$ pada pembuatan metil ester (biodiesel) telah dilaporkan Hadrah et al., 2018; Moeksin et al., 2017; Ningtyas, 2013; (Harahap \& Yullia, 2018; Permana et al., 2020; Setiawati \& Edwar, 2012). Dalam laporan mereka menjelaskan bahwa penggunaan katalis yang tepat dalam reaksi transesterifikasi sangat berpengaruh terhadap rendemen metil ester. Selain itu kualitas bahan baku yang mengandung asam lemak bebas sangat menentukan mutu biodiesel yang dihasilkan.

Proses pemurnian bahan baku minyak jelantah juga mempengaruhi hasil rendemen dan kualitas biodiesel yang berbeda-beda. Berdasarkan laporan (Ahmad et al., 2016)(Efendi et al., 2018b)(Majid et al., 2012)(Darmawan, 2013) telah diketahui bahwa rendemen dan kualitas biodiesel memberikan nilai sangat bervariasi. (Darmawan, 2013; Efendi et al., 2018a) melakukan pemurnian minyak jelantah melalui proses degumming (penghilangan getah) dengan asam $\mathrm{HCl}$ menghasilkan rendemen $84 \%$, sedangkan (Majid et al., 2012)melakukan pemurnian bahan baku minyak jelantah dengan cara bleaching (pemutihan) menghasilkan rendemen $97 \%$. Seluruh penelitian tersebut menunjukkan nilai seluruh parameternya sesuai Standar Nasional Indonesia (SNI).

Proses pemurnian dengan penambahan proses kerja dan bahan kimia seperti yang telah diteliti sebelumnya tentu memberikan pengaruh terhadap biaya dan dampak lingkungan lainnya. Pemurnian bahan baku minyak jelantah yang mudah dan tidak membutuhkan bahan kimia tambahan dianggap memberikan keuntungan tersendiri. Oleh karena itu maka dalam laporan ini akan dipelajari bagaimana pengaruh rendemen dan kualitas biodiesel dari minyak jelantah tanpa pemurnian dengan bahan kimia.

Berdasarkan latar belakang di atas maka pada penelitian ini akan dipelajari pengaruh kosentrasi \% massa katalis $\mathrm{NaOH}$ dari jumlah total metanol dan minyak jelantah dengan variasi 0,$4 ; 0,5 ; 0 ; 6$; dan $0,7 \%$ massa katalis $\mathrm{NaOH}$ terhadap perolehan biodiesel dari bahan baku minyak jelantah tanpa proses pemurnian dengan bahan kimia. Katalis basa $\mathrm{NaOH}$ dipilih karena harganya murah, mudah didapatkan dan dikenal memiliki efektifitas katalisis yang baik dalam reaksi transesterfikasi minyak nabati dan hewani. Seluruh sampel akan dipelajari sifat kimia (\% FFA, kadar Air, pH), kandungan dan sifat fisikanya (flash point, densitas, warna), kemudian akan dibandingkan dengan standar SNI Biodisel. Untuk menentukan jenis, dan komposisi asam lemak dan kadar yang terkandung dalam sampel hasil reaksi transesterifikasi tersebut dapat dilakukan menggunakan instrument kromatografi gas (GC) dan spektroskopi massa (MS). Metode GC ini 
juga mampu memberikan informasi turunan asam lemak dalam sampel. Metode analisis Massa Spectroscopy (MS) digunakan untuk menentukan fragmentasi asam lemak jenuh dan tak jenuh seperti yang telah dilaporkan oleh Ningtyas, 2013;(Muderawan \& Daiwataningsih, 2016; Setiawati \& Edwar, 2012)) dan masih banyak lagi.

\section{Metode Penelitian}

Penelitian ini dilakukan secara eksperimental di Laboratorium Kimia kampus STT Migas Balikpapan. Pengukuran Gas Chromatography (GC)-Massa Spectroscopy (MS) dilakukan di Laboratorium Terpadu Universitas Islam Indonesia. Bahan baku yang digunakan adalah minyak jelantah yang telah digunakan sebanyak 6 kali pemakaian dari pedagang gorengan di sekitar kampus STT Migas Balikpapan. Bahan kimia berupa NaOH 99\% pa, Metanol 98\%, $\mathrm{CH} 3 \mathrm{COOH} 98 \%$, aquades, indikator Phenoptalen (PP). Alat-alat yang digunakan pada penelitian ini seperangkat alat reaktor reflux (labu leher tiga 500 $\mathrm{mL}$, termometer, pengaduk magnet, pemanas listrik dan sistem pendingin) sistem pendingin, kromotografi gas spektroskopi massa (GC-MS) QP type 2010 SE, vial injeksi, alat-alat gas, dan timbangan digital.

\subsection{Preparasi Awal minyak jelatah}

Preparasi Awal minyak jelantah bertujuan untuk menghilangkan air dan pengotor. Proses pemisahan dilakukan melalui pemanasan $500 \mathrm{ml}$ minyak jelantah pada suhu $100^{\circ} \mathrm{C}-120^{\circ} \mathrm{C}$ sembari di aduk selama kurang lebih 10 menit (untuk menghilangkan kadar air). Penyaringan minyak jelantah (untuk menghilangkan kotoran yang berupa padatan). Bahan baku minyak jelantah yang telah bersih dari pengotor kemudian di lakukan karakterisasi dengan melakukan pengukuran densitas, kadar air, \% FFA, pH dan identifikasi warna. Seluruh data ini di laporkan sebagai karakteristik awal bahan baku minyak jelantah

\subsection{Reaksi Transesterfikasi Minyak Jelantah}

Minyak jelantah yang telah dipreparasi kemudian langsung diproses lebih lanjut melalui reaksi transesterifikasi. Masing-masing $\mathrm{NaOH}$ dengan variasi berturut-turut 0,$4 ; 0,5 ; 0,6 ; 0,7 \%$ massa dari massa total minyak jelantah dan metanol. $\mathrm{NaOH}$ ditimbang kemudian dicampurkan dalam $100 \mathrm{ml}$ metanol dalam gelas beker $250 \mathrm{ml}$, diaduk hingga homogen. Setelah didapatkan larutan yang homogen kemudian ditempatkan dalam labu leher tiga. Sebanyak $500 \mathrm{ml}$ minyak jelantah dimasukan dalam labu leher tiga yang telah berisi larutan campuran $\mathrm{NaOH}$ dan Metanol. Seluruh campuran kemudian dipanaskan selama 120 menit pada suhu $60^{\circ} \mathrm{C}$ dengan pengadukan tetap. Campuran hasil transestrifikasi didiamkan selama 24 jam didalam corong pisah (biodiesel pada bagian atas dan gliserol pada bagian bawah). Pencucian lapisan biodiesel diakukan dengan aquades hingga $\mathrm{pH}$ netral. Metil ester yang telah di dapatkan kemudian direfluks untuk menghilangakn air pada suhu $100^{\circ} \mathrm{C}$.

\subsection{Identifikasi Sifat Fisika dan Kimia Metil Ester} meliputi:

Seluruh sampel hasil reaksi transesterfikasi dipelajari sifat fisika dan kimia 
a. Densitas merupakan perbandingan nilai massa terhadap volume metil ester

$\rho=\frac{m}{v}=\frac{\text { piknoisi }- \text { pilmo tosong } g}{v(m l)}$

Keterangan : $\rho=$ (Massa Jenis) $, M=($ Massa $), V=$ (Volume $)$

b. Free Fatty Acid (\% FFA), kadar \% FFA diukur dengan mentitrasi biodiesel dalam metanol dengan larutan $\mathrm{NaOH}$ yang telah di bakukan dengan Aquades dan phenolphthalein (pp).

$\%$ FFA $=\frac{m L \text { NaOH } X N \text { NaOH } X \text { BM Sampel }}{m X 1000} X 100 \%$

c. Perhitungan rendemen dilakukan dengan cara menghitung massa metil ester yang dihasilkan tanpa pengotor dengan jumlah bahan baku minyak jelantah. Perhitungan rendemen biodiesel dilakukan menggunakan rumus :

Rendomen $(\%)=\frac{\text { Jumlah Minyak yang dihasilkan }}{\text { Jumlah bahan sebelum di olah }}$ X 100.

d. Pengujian kadar air dengan cara, volume biodiesel setelah dicuci kemudian dikurang volume biodiesel setelah di uapkan diupakan. Adapun rumus perhitngan yang dipakai dalam perhitungan volume air :

Air $r=\frac{v \text { Biodiesel setelah dicuei-v Biodiesel setelah diwapkan }}{v(v \text { Biodiesel setelah di cuci) }} X 100 \ldots . .(4)$

e. Titik nyala, pengujian titik nyala dilakukan dengan menggunakan alat uji ASTM D92,

f. $\mathrm{pH}$ diukur menggunakan kertas lakmus universal pada bahan baku dan metil ester hasil reaksi

g. Warna, Pengujian warna dilakukan dengan cara memasukan sample sampel ke dalam tabung reaksi yang telah diberi label penanda lalu diidentifikasi warna sampel secara visual.

h. Destilasi, pengujian destilasi dilakukan dengan menggunakan alat uji ASTM D92, untuk menghitung IBP dan FBP.

\subsection{Indentifikasi Metil Ester dengan Gas Chromatography (GC)- Massa Spectroscopy (MS.)}

Penentuan komponen metil ester (biodosel) hasil reaksi transesterifikasi minyak jelantah dan metanol oleh katalis basa $\mathrm{NaOH}$ di Laboratorium Terpadu Universitas Islam Indonesia dengan menggunakan seperangkat alat Gas Chromatography (GC)-Massa Spectroscopy (MS). Pengukuran dilakukan dengan kenaikan $10^{\circ} \mathrm{C} /$ menit dari suhu $25^{\circ} \mathrm{C}$ sampai suhu $299^{\circ} \mathrm{C}$ selama 29,633 menit, dan detector menggunakan MS (Massa Spektrometer).

\section{Hasil dan Pembahasan}

\subsection{Identifikasi Bahan Baku Minyak Jelantah}

Tabel 1. di bawah ini memuat tentang hasil identifikasi awal sifat kimia dan fisika bahan baku minyak jelantah. Identifikasi tentang bahan baku yang akan digunakan dalam proses pembuatan metil ester (biodiesel) harus dilakukan untuk menentukan arah reaksi yang tepat dalam proses pembuatan biodiesel. 
Tabel 1. Karakteristik Awal Bahan Baku Minyak Jelantah

\begin{tabular}{cccc}
\hline No & Pengujian & Satuan & Nilai \\
\hline 1 & Densitas & $\mathrm{Kg} / \mathrm{m}^{3}$ & 870 \\
\hline 2 & Kadar Air & $\%$-volume & 0,073 \\
\hline 3 & FFA & $\%$ & 0,419 \\
\hline 4 & $\mathrm{pH}$ & - & 6,05 \\
\hline 5 & Warna & - & Kuning kecoklatan \\
\hline
\end{tabular}

Sumber: diolah dari hasil penelitian 2021

Berdasarkan data pada Tabel 1 di atas diketahui bahwa bahan baku minyak jelantah memiliki densitas $870 \mathrm{Kg} / \mathrm{m}^{3}$, pH netral, kadar air rendah sebesar $0,073 \%$ volume serta kadar Free Fatty Acid (\% FFA) sebesar 0,419 \%. Menurut Prastyo, dkk 2011; Viriya-Empikul, dkk, 2012; dan Mosaddegh, dkk, 2013, jika kadar \% FFA $>2 \%$ maka untuk mendapatkan biodiesel harus dilakukan proses esterifikasi terlebih dahulu untuk menurunkan kadar \% FFA, namun jika \% FFA $<2 \%$ maka pembuatan biodiesel dapat dilakukan menggunakan katalis basa yang dikenal sebagai proses transesterfikasi. Kadar \% FFA yang $>2 \%$ dapat mengganggu proses pembentukan metil ester karena adanya reaksi safonifikasi (penyabunan) (Hossain \& Mazen, 2010; Ma \& Hanna, 1999; Prasetyo, 2018).

\subsection{Reaksi transesterifikasi}

Menurut reaksi transesterifikasi berlangsung bolak-balik, dimana salah satu reaktan (metanol) harus dibuat berlebih agar diperoleh hasil yang optimal. Metanol yang berlebihan dapat meningkatkan hasil konversi metil ester secara optimal (Greever, 1995) Reaksi transesterifikasi menggunakan katalis basa golongan logam alkali alkoksida dari alkohol dengan suatu basa alkali seperti $\mathrm{NaOH}$. Reaksi antara metanol dengan $\mathrm{NaOH}$ membentuk senyawa natrium metoksida (alkoksida) yang di tunjukan pada gambar 1. Menurut (Greever, 1995), nukleofil pada reaksi transesterifikasi adalah gugus alkoksida (:OR). Reaksi pembentukan metil ester dalam kondisi basa suatu ester dengan ion alkoksida adalah reaksi substitusi nukleofilik melalui pembentukan intermediet tetrahedral antara ion metoksida dan Alkil Alkanoat.
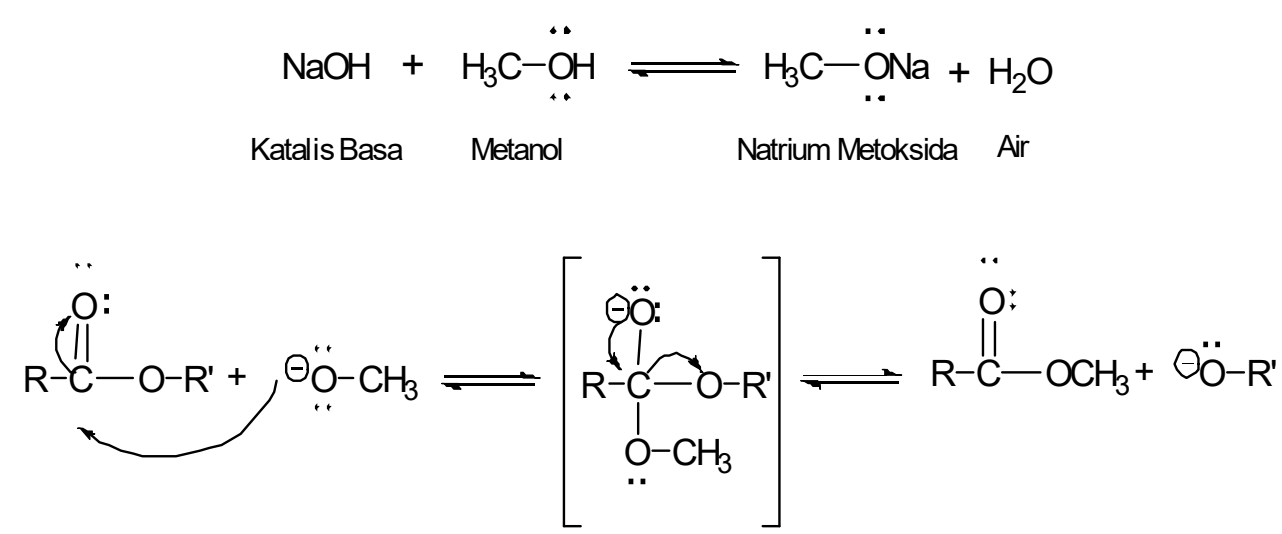

$\begin{array}{llll}\text { Alkil Alkanoat } \quad \text { ion metoksida } & \begin{array}{l}\text { Intermediet Tetrahedral } \\ \text { ion metoksida dan AlkilAlkanoat }\end{array} & \text { metil ester } & \text { ion Alkoksida }\end{array}$

Gambar 1. Mekanisme reaksi TRansesterfikasi transesterifikasi pada pembentukan metil ester dengan katalis basa $\mathrm{NaOH}$ (Greever, 1995) 
Hasil reaksi transesterifikasi minyak jelantah dengan metanol dengan bantuan katalis $\mathrm{NaOH}$ ditunjukkan pada Gambar 2. Grafik di bawah ini menunjukkan hubungan pengaruh \% massa katalis $\mathrm{NaOH}$ dari jumlah total metanol dan minyak dengan perabandingan 1:5 terhadap rendemen produk metil ester (biodiesel) hasil reaksi. Kondisi reaksi dipertahankan selama 120 menit pada suhu $60^{\circ} \mathrm{C}$ dengan pengadukan tetap.

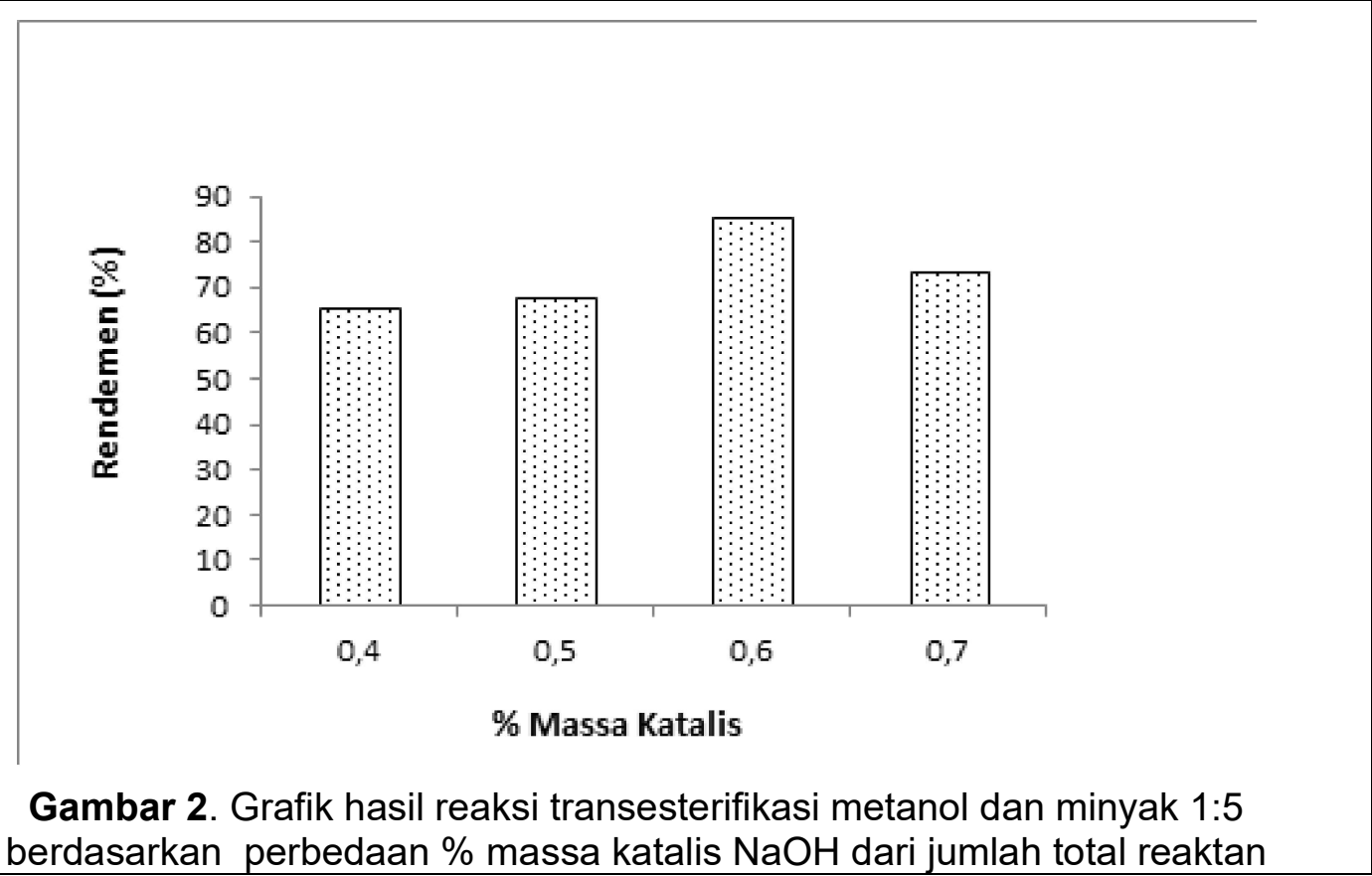

Sumber: diolah dari hasil penelitian 2021

Berdasarkan gambar 2 diatas di atas diketahui bahwa rendemen tertinggi terdapat pada $0,6 \%$ massa katalis $\mathrm{NaOH}$ dengan perolehan sebesar $85 \%$.

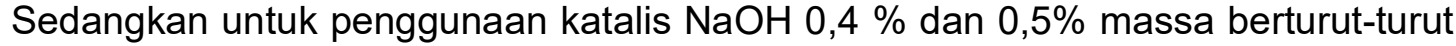
sebesar 65,5 dan 67,8 \%. Namun pemberian katalis $\mathrm{NaOH} 0,7 \%$ massa menunjukkan adanya pengurangan rendemen produk metil ester yaitu hanya sebesar $72 \%$. Diduga penggunaan katalis basa $\mathrm{NaOH}$ berlebih menyebabkan pembentukkan sabun (saponifikasi).Pada kondisi katalis $\mathrm{NaOH}$ berlebih terjadi reaksi kompetisi pembentukan metil ester dan reaksi penyabunan. Hal ini disebabkan jumlah katalis basa $(\mathrm{NaOH})$ yang diberikan sangat berlebih, dan pada kondisi reaksi saponifikasi, air yang terbentuk berekasi dengan katalis sehingga jumlah metil ester yang diharapkan menjadi berkurang (Mastukik, 2006).

\subsection{Identifikasi Metil Ester (biodiesel) Hasil Reaksi Transesterfikasi}

Pada Tabel 2 di bawah ini adalah hasil identifikasi metil ester reaksi transesterifikasi. Pengujian densitas yang didapatkan dari sampel 1 menunjukkan angka $0,826826 \mathrm{Kg} / \mathrm{m}^{3}$, sampel 2 menunjukkan angka $822 \mathrm{Kg} / \mathrm{m}^{3}$, sampel 3 menunjukkan angka $825 \mathrm{Kg} / \mathrm{m}^{3}$, dan sampel 4 menunjukkan angka $815 \mathrm{Kg} / \mathrm{m}^{3}$. Berdasarkan Standar Nasional Indonesia (SNI) tentang densitas yakni 850-890 $\mathrm{Kg} / \mathrm{m}^{3}$, semua variasi sampel tidak memenuhi syarat. Tidak terpenuhinya nilai densitas pada semua sampel dikarenakan tidak dilakukan proses pemurnian dari bahan baku minyak jelantah. Hal ini berbeda jika di lakukan pemurnian seperti yang telah di laporkan sebelumnya oleh (Darmawan, 2013; Efendi et al., 2018a) 
melakukan pemurnian minyak jelantah melalui proses degumming (penghilangan getah) dengan asam $\mathrm{HCl}$, sedangkan (Majid et al., 2012)melakukan pemurnian bahan baku minyak jelantah dengan cara bleaching (pemutihan) menghasilkan seluruh biodiesel hasil reaksi telah memenuhi SNI.

Tabel 2. Karakterisasi metil ester hasil reaksi transesterifikasi metanol dan minyak $1: 5$ berdasarkan perbedaan \% massa katalis $\mathrm{NaOH}$

\begin{tabular}{|c|c|c|c|c|c|c|}
\hline \multirow{2}{*}{ Pengujian } & \multirow{2}{*}{ Satuan } & \multirow{2}{*}{ Nilai SNI } & \multicolumn{4}{|c|}{ Hasil Reaksi Transesterifikasi } \\
\hline & & & $0,4 \%$ & $0,5 \%$ & $0,6 \%$ & $0,7 \%$ \\
\hline Densitas & $\mathrm{Kg} / \mathrm{m}^{3}$ & $850-890$ & 826 & 822 & 835 & 815 \\
\hline Titik Nyala & ${ }^{\circ} \mathrm{C}$ & Min 100 & 176 & 182 & 185 & 176 \\
\hline $\begin{array}{c}\text { Destilasi } \\
90 \%\end{array}$ & ${ }^{\circ} \mathrm{C}$ & Maks 360 & 352 & 354 & 350 & 335 \\
\hline Kadar Air & $\%$-volume & Maks 0,05 & 0,073 & 0,071 & 0,011 & 0,026 \\
\hline FFA & $\%$ & Maks 0.8 & 0,16 & 0,192 & 0,32 & 0,64 \\
\hline Warna & - & $\begin{array}{c}\text { Kuning } \\
\text { Emas }\end{array}$ & $\begin{array}{c}\text { Kuning } \\
\text { Emas }\end{array}$ & $\begin{array}{c}\text { Kuning } \\
\text { Emas }\end{array}$ & $\begin{array}{c}\text { Ku ning } \\
\text { Emas }\end{array}$ & $\begin{array}{c}\text { Kuning } \\
\text { Emas }\end{array}$ \\
\hline $\mathrm{pH}$ & - & 6 & 6 & 6 & 6 & 6 \\
\hline
\end{tabular}

Sumber: diolah dari hasil penelitian 2021

Berdasarkan hasil pengujian titik nyala (flash point) dari sampel yang diuji katalis dengan 0,$4 ; 0,5 ; 0 ; 6$; dan $0,7 \%$ massa katalis $\mathrm{NaOH}$ dari jumlah total metanol dan minyak jelantah berturut-turut adalah sebesar $176{ }^{\circ} \mathrm{C}, 182{ }^{\circ} \mathrm{C}, 185^{\circ} \mathrm{C}$, dan $176{ }^{\circ} \mathrm{C}$. Titik nyala yang tinggi akan memudahkan penanganan bahan bakar, karena tidak perlu disimpan pada suhu rendah, sebaliknya titik nyala yang terlalu rendah akan membahayakan karena tingginya resiko terjadi penyalaan (Ma \& Hanna, 1999). Berdasarkan Standar Nasional Indonesia (SNI) mengenai titik nyala yakni pada suhu minimal $100{ }^{\circ} \mathrm{C}$, semua variasi sampel memenuhi syarat.

Berdasarkan Standar Nasional Indonesia (SNI) mengenai destilasi 90\% maksimal $360{ }^{\circ} \mathrm{C}$, semua variasi sampel telah memenuhi syarat. Uji kandungan kadar air adalah penentuan kandungan air yang terdapat pada produk biodiesel. Jika dalam suatu produk biodiesel mengandung kadar air yang melebihi standar SNI yaitu 0,05 \%-Volume dari sampel maka dikawatirkan di khawatirkan akan menyebabkan masalah dalam sistem mesin kendaraan. Makin kecil kadar air dalam minyak maka mutunya akan semakin baik pula karena akan memperkecil terjadinya hidrolisis yang dapat menyebabkan kenaikan kadar asam lemak bebas. Kandungan air dalam bahan bakar dapat juga menyebabkan turunnya panas pembakaran, berbusa dan bersifat korosif jika bereaksi dengan sulfur karena akan membentuk asam (Ma \& Hanna, 1999; Prasetyo, 2018). Berdasarkan Standar Nasional Indonesia (SNI) mengenai kandungan air tidak boleh lebih dari 0,05\%Volume dari sampel. Dari hasil pengujian kadar air diketahui bahwa sampel 0,4\% dan $0,5 \%$ massa katalis $\mathrm{NaOH}$ melebihi SNI yakni berturut-turut sebesar 0,073 
dan $0,071 \%$ volume. Sedangkan sampel $0,6 \%$ dan $0,7 \%$ massa katalis $\mathrm{NaOH}$ telah masuk SNI yakni berturut-turut sebesar 0,0116 dan $0,026 \%$ volume.

Standar Nasional Indonesia (SNI) mengenai kadar asam yang terkandung dalam biodiesel memiliki batasan yakni maksimum $0,8 \mathrm{Mg} / \mathrm{KOH} / \mathrm{g}$ jika sampel yang memiliki angka di atas maksimum tersebut maka akan menyebabkan korosif dan dapat menimbulkan kerak pada injektor mesin diesel (Prastyo et al., 2011). Berdasarkan dari hasil tersebut dibandingkan dengan SNI maka semua sampel telah memenuhi batasan angka asam yang ditetapkan.

\subsection{Analisis Metil Ester dengan Gas Chromatography (GC)- Massa Spectroscopy (MS.)}

Analisis kandungan asam lemak dapat dilakukan melalui pemisahan secara kuantitatif dengan metode Gas Chromatography (GC). Metode GC ini juga mampu memberikan informasi turunan asam lemak dalam sampel. Metode analisis Massa Spectroscopy (MS) digunakan untuk menentukan fragmentasi asam lemak jenuh dan tak jenuh, dan letak ikatan rangkap jenis asam lemak (Ningtyas, 2013). Gambar 3 menunjukkan hasil identifikasi GC metil ester sampel 0,6 \% massa katalis $\mathrm{NaOH}$. Sampel $0,6 \%$ massa katalis $\mathrm{NaOH}$ dipilih untuk di uji diuji kandungan metil ester dengan GC-MS karena telah diketahui sebelumnya memiliki hasil rendemen yang paling baik yaitu $85 \%$ serta di karenakan nilai SNI untuk pengukuran titik nyala, kadar air, $\mathrm{pH}$ dan \% FFA telah memenuhi. Hasil Kromatogram yang diperoleh menunjukan adanya 14 puncak dengan waktu retensi $\left(t_{R}\right)$ dam luas area puncak (\%) seperti pada gambar 3 .

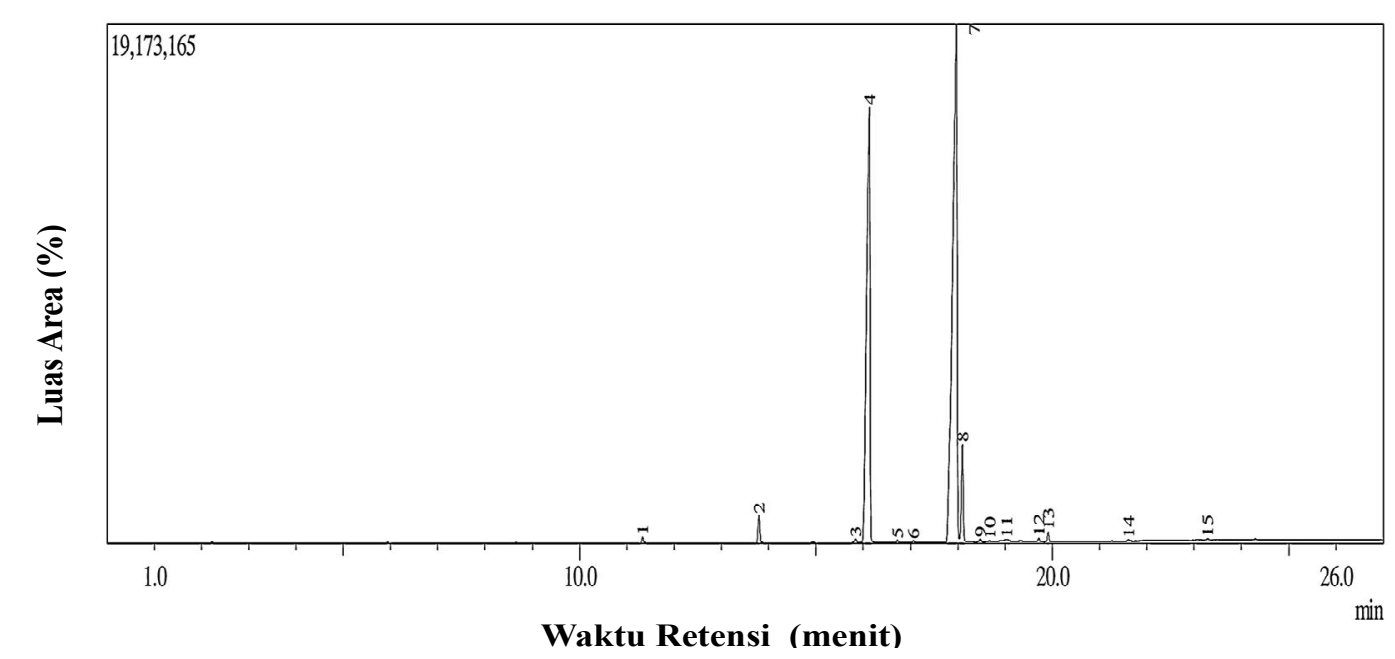

Gambar 3. Grafik Hasil Pengukuran Gas Chromatography (GC) senyawa hasil reaksi transesterifikasi metanol dan minyak $1: 5$ pada $0,6 \%$ massa katalis $\mathrm{NaOH}$

Sumber: diolah dari hasil penelitian 2021

Analisis GC-MS pada metil ester hasil reaksi transesterfikasi menunjukan jumlah dan jenis ester yang berbeda. Hal ini ditandai dengan adanya 14 puncakpuncak senyawa ester yang muncul dengan puncak tajam dan waktu retensi yang berbeda-beda (Gambar 3). Jenis ester rantai pendek bersifat polar daripada ester rantai panjang (Greever, 1995). Prinsip pemisahan like dissolve like menjadi acuan bahwa jenis ester dengan rantai yang lebih panjang memiliki waktu retensi 
(retention time, $t_{R}$ ) yang lebih lama. Detektor pada GC akan telebih dahulu membaca senyawa yang memiliki rantai hidrokarbon pendek karena sangat mudah terbawa oleh fasa gerak. Hal ini dikarenakan waktu tinggal rantai karbon pendek berinteraksi lemah dengan kolom jika dibandingkan dengan rantai panjang. Rantai pendek polar akan lebih awal muncul daripada rantai panjang non polar. Asam lemak mempunyai gugus karboksilat tunggal dan rantai hidrokarbon non-polar, menyebabkan lemak tidak larut dalam air (Greever, 1995).

Analisis GC-MS telah mengidentifikasi terdapat 3 puncak yang memiliki nilai luas area yang lebih tinggi dari 14 puncak yang terdeteksi sebagai metil ester atau asam lemak. Kromatogram hasil deteksi GC-MS menunjukkan bahwa 3 puncak tertinggi tersebut masing-masing adalah puncak 7 merupakan metil oleat $\left(\mathrm{C}_{19} \mathrm{H}_{36} \mathrm{O}_{2}\right)$, luas area $55,47 \%$ dan waktu retensi 17,967 menit; puncak 4 adalah metil palmitat $\left(\mathrm{C}_{17} \mathrm{H}_{34} \mathrm{O}_{2}\right)$ dengan luas area $36,66 \%$ dan waktu retensi 16,127 menit; serta puncak 8 adalah metil stearate $\left(\mathrm{C}_{19} \mathrm{H}_{38} \mathrm{O}_{2}\right)$ dengan luas area $4,41 \%$ dan waktu retensi 18,101 menit. Sedangkan puncak 2 menunjukkan nilai yang rendah dengan luas area 1,15\% waktu retensi 13,794. Puncak 2 berdasarkan analisis MS menunjukkan adanya molekul metil meristat $\left(\mathrm{C}_{15} \mathrm{H}_{30} \mathrm{O}_{2}\right)$

Berdasarkan luas area tersebut bahwa metil oleat memiliki kelimpahan yang paling besar. Menurut (Gultom, 2001; Ma \& Hanna, 1999) asam palmitat merupakan asam lemak jenuh terpenting, sedangkan asam oleat yang berisi satu ikatan rangkap merupakan asam lemak tak jenuh terpenting. Biofuel yang mengandung asam lemak jenuh tinggi merupakan metil ester yang tahan terhadap oksidasi dari udara, dan mempunyai bilangan oktan yang tinggi (Gultom, 2001). Spektra massa masing-masing senyawa ditunjukkan pada Gambar 4,5, 6 dan 7.

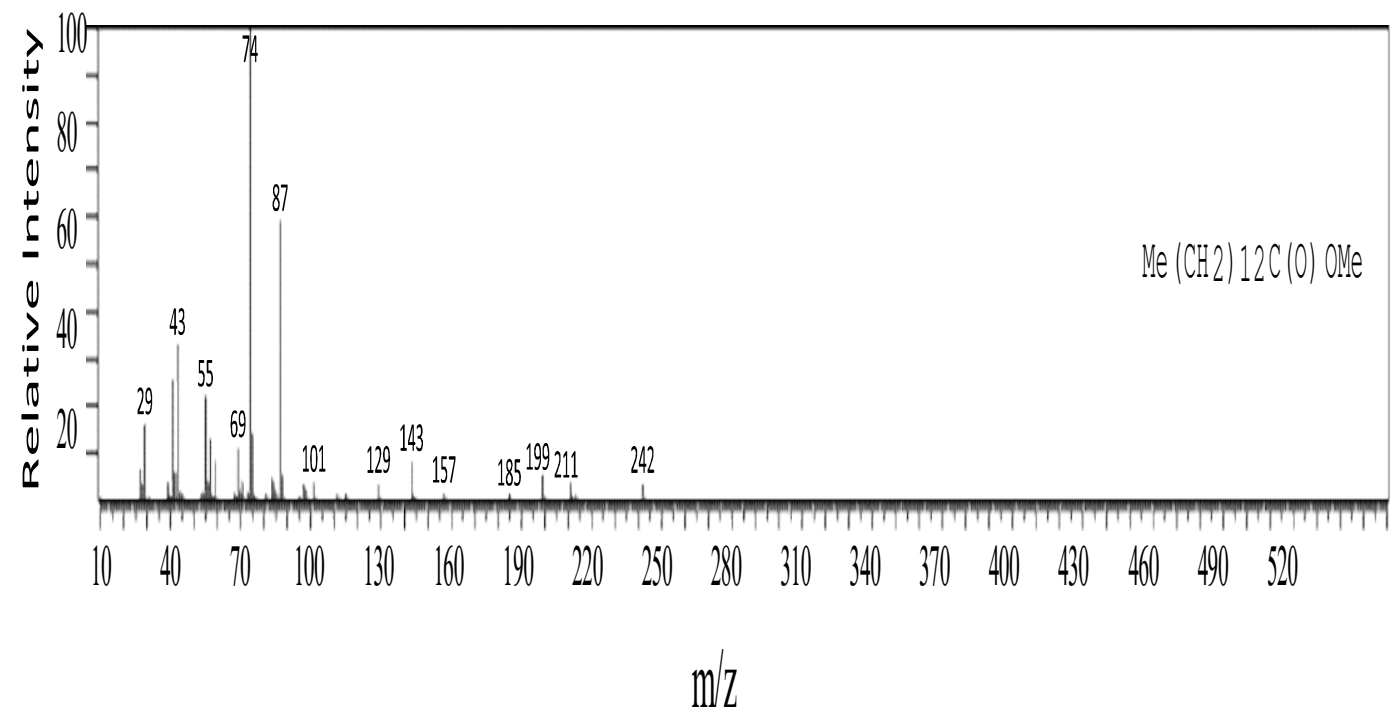

Gambar 4. Spektra Massa Spectroscopy (MS) senyawa puncak 2 metil meristat, waktu retensi ( $\left.t_{R}\right) 13,794$ menit, luas puncak 1,15\%

Sumber: diolah dari hasil penelitian 2021 


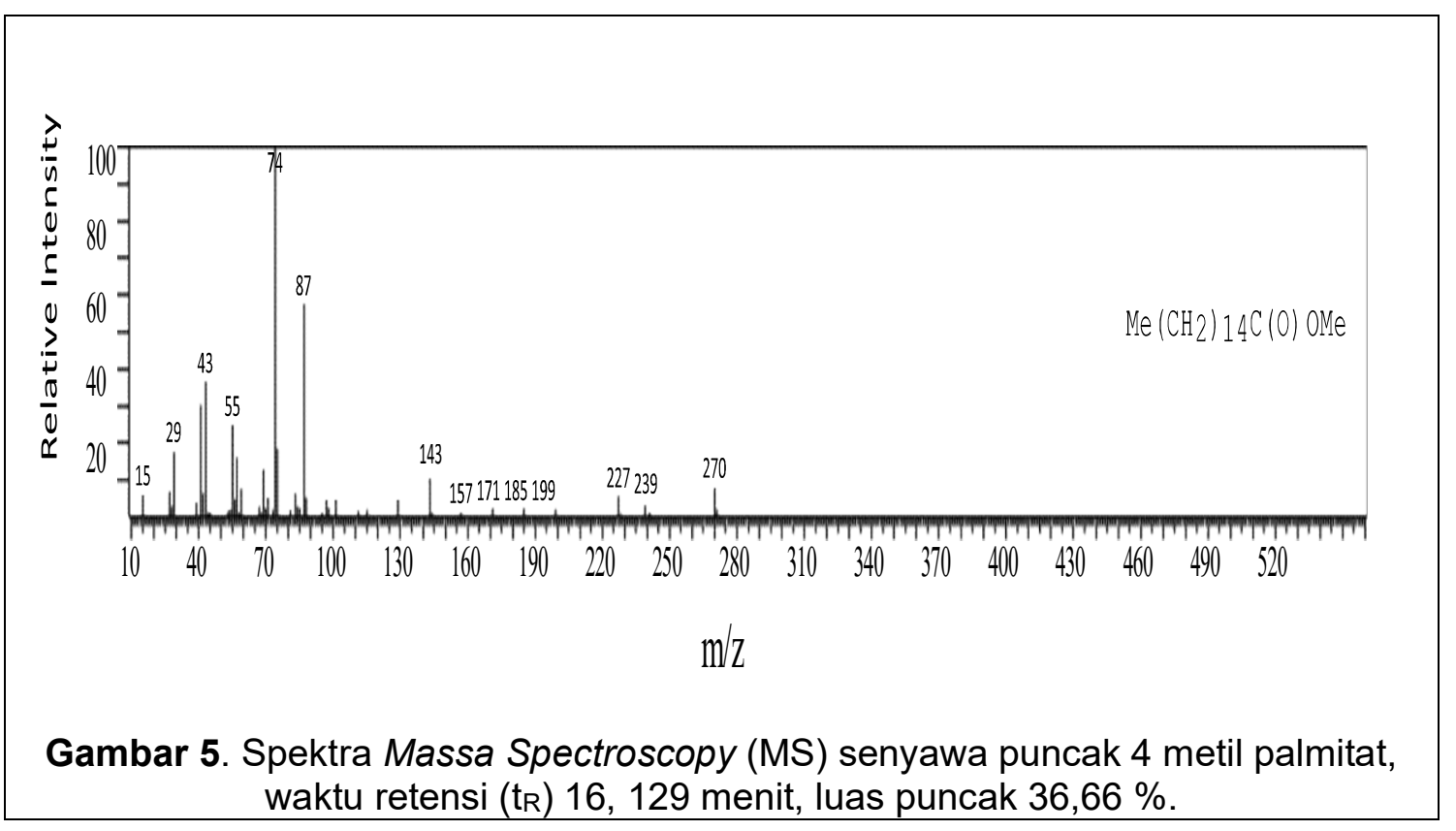

Sumber: diolah dari hasil penelitian 2021

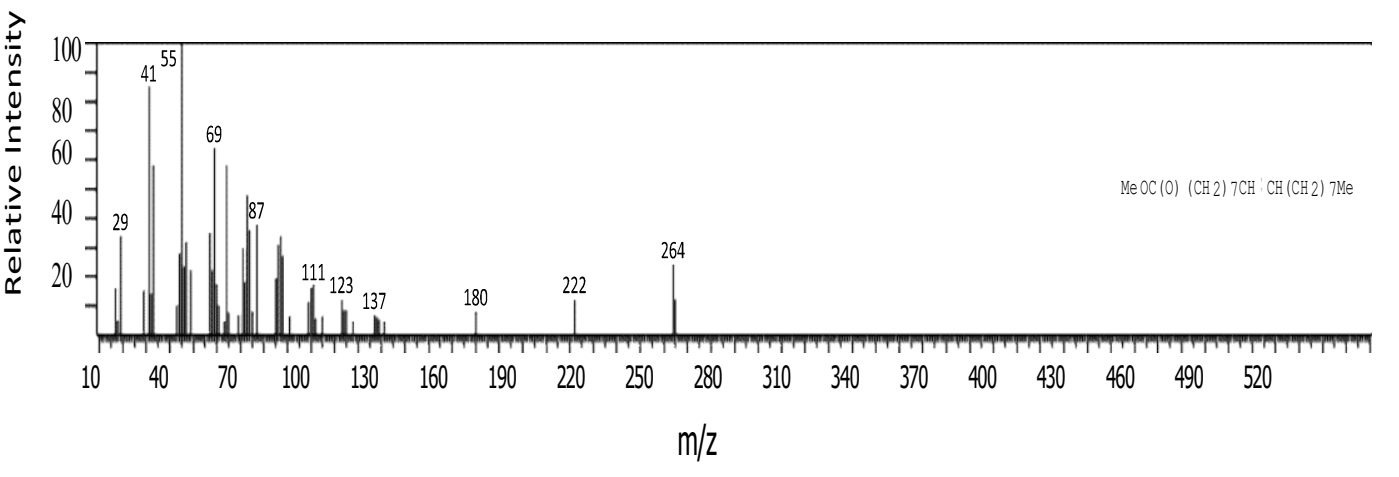

Gambar 6. Spektra Massa Spectroscopy (MS) senyawa puncak 7 metil oleat, waktu retensi ( $\left.t_{R}\right)$ 17,967 menit, luas puncak $55,47 \%$

Sumber: diolah dari hasil penelitian 2021 


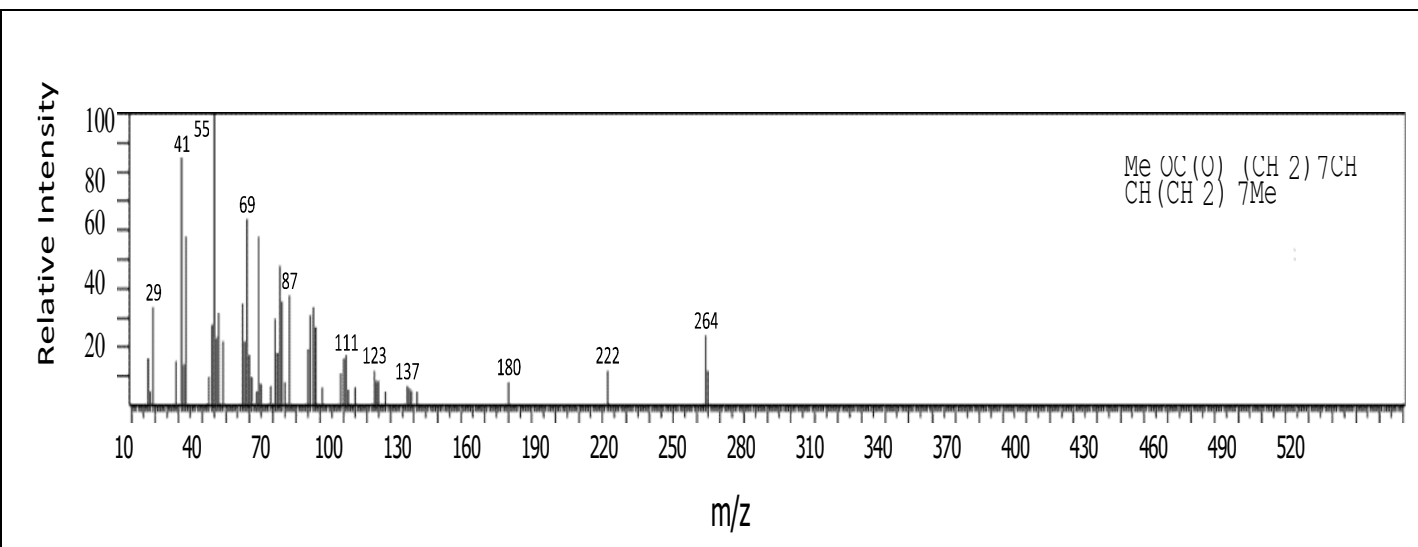

Gambar 7. Spektra Massa Spectroscopy (MS) senyawa puncak 8 metil stearat, waktu retensi $\left(t_{R}\right) 18,101$ menit, luas puncak 4,41\%

Sumber: diolah dari hasil penelitian 2021

Analisis spketroskopi massa menunjukkan spektrum massa senyawa metil ester bervariasi seperti pada gambar 4, 5, 6, dan 7. Seluruh metil ester menunjukkan spektrum yang khas terhadap masing-masing senyawa yang bergantung pada berat molekulnya. Berdasarkan spektrum di atas yang kemudian di tuangkan dalam tabel 3 di bawah ini, diketahui metil meristat memiliki berat molekul 242 yang akan terbaca terlebih dahulu dengan waktu retensi singkat 13,785 menit. Kemudian akan terbaca puncak 4 metil palmitat berat molekul 270 dengan waktu retensi 16,123 menit, serta disusul oleh metil oleat dan metil stearat dengan berat molekul masing-masing 295,5 dan 298. Hasil spektrum tersebut menunjukkan bahwa semakin berat molekul suatu senyawa maka semakin lama waktu retensinya yang artinya interaksi terhadap kolom alat gas kromatografi semakin lama (Karasek \& Clement, 2012). Melalui mekanisme pemisahan GC-MS ini maka telah di ketahui dengan pasti kandung penyusun metil ester dalam sampel hasil reaksi transesterifikasi.

Tabel 3. Analisis Massa Spectroscopy (MS) senyawa hasil reaksi transesterifikasi metanol dan minyak $1: 5$ pada $0,6 \%$ massa katalis $\mathrm{NaOH}$

\begin{tabular}{ccccc}
\hline $\begin{array}{c}\text { Waktu } \\
\begin{array}{c}\text { Retensi, } t_{R} \\
\text { (menit) }\end{array}\end{array}$ & Rumus Molekul & $\begin{array}{c}\text { Nama } \\
\text { Senyawa }\end{array}$ & Berat Molekul & $\begin{array}{c}\text { Luas } \\
\text { Puncak } \\
(\%)\end{array}$ \\
\hline 13,785 & $\mathrm{C}_{15} \mathrm{H}_{30} \mathrm{O}_{2}$ & Metil Miristat & 242 & 1,15 \\
\hline 16,123 & $\mathrm{C}_{17} \mathrm{H}_{34} \mathrm{O}_{2}$ & Metil Palmitat & 270 & 36,66 \\
\hline 17,967 & $\mathrm{C}_{19} \mathrm{H}_{36} \mathrm{O}_{2}$ & Metil Oleat & 296,5 & 55,47 \\
\hline 18,101 & $\mathrm{C}_{19} \mathrm{H}_{38} \mathrm{O}_{2}$ & Metil Stearat & 298 & 4,41 \\
\hline & & & \\
\hline
\end{tabular}

\section{Kesimpulan}

Reaksti transesterfikasi minyak jelantah dan metanol memberikan hasil rendemen terbaik pada katalis $\mathrm{NaOH} 0,6 \%$ massa sebesar $85 \%$. Sedangkan untuk 
penggunaan katalis $\mathrm{NaOH} 0,4 ; 0,5$; dan $0,7 \%$ massa katalis adalah masingmasing $65,5 \%, 67,8 \%$ dan $72 \%$. Instrumen Gas Chromatography (GC) dan Mass Spectrocopy (MS) telah mampu mendeskripsikan secara kualitatif dan kuantitatif kandungan biodiesel sintetik. Analisis GC-MS telah mengidentifikasi 3 puncak yang memiliki nilai area lebih tinggi dari 14 puncak yang terdeteksi sebagai metil ester asam lemak. Hasil kromatogram deteksi GC-MS menunjukkan bahwa 3 puncak tertinggi adalah pada pucak ker 7 puncak ke 7 yaitu metil oleat, luas area $64,6255,47 \%$ dan waktu retensi 17,9217,967 menit; puncak ke 4 adalah metil palmitat dengan luas $25,3336,66 \%$ dan waktu retensi $17,9216,127$ menit; dan puncak ke 8 adalah methyl nonadecanoatemetil stearat dengan luas 4,8741\% dan waktu retensi 18.09318,101 menit. Sementara itu, puncak 2 adalah terendah menunjukkan bahwa senyawa metil miristat dan siklooktadekanol masing-masing sebesar $1,12 \%$ dan $1,45 \%$.metil mersitat dengan luas area hanya $1,15 \%$

\section{Ucapan Terima Kasih}

Penulis mengucapkan terimakasih kepada pemberi dana kegiatan penelitian ini melalui program hibah internal LPPM STT Migas Balikpapan. Program ini adalah wajud visi dari misi STT Migas Balikpapan untuk menjadi perguruan tinggi yang unggul di Kalimantan Timur

\section{Daftar Pustaka}

Ahmad, H. S., Bialangi, N., \& Salimi, Y. K. (2016). Pengolahan minyak jelantah menjadi biodiesel. Jambura Journal of Educational Chemistry, 11(2), 204214.

Darmawan, F. I. (2013). Proses Produksi Biodiesel dari Minyak Jelantah dengan Metode Pencucian Dry-Wash Sistem. Jurnal Teknik Mesin, 2(01).

Efendi, R., Faiz, H. A. N., \& Firdaus, E. R. (2018a). Pembuatan Biodiesel Minyak Jelantah Menggunakan Metode Esterifikasi transesterifikasi Berdasarkan Jumlah Pemakaian Minyak Jelantah. Prosiding Industrial Research Workshop and National Seminar, 9, 402-409.

Greever, J. C. (1995). Organic Chemistry, (Fessenden, Ralph J.; Fessenden, Joan S.). ACS Publications.

Gultom, T. (2001). Individual Textbook Biokimia. Jurusan Pendidikan Kimia Fakultas MIPA Universitas Negeri Yogyakarta, Yogyakarta.

Harahap, J., \& Yullia, Y. (2018). Potensi Pemanfaatan Limbah Minyak Jelantah Kota Banda Aceh Sebagai Sumber Energi Alternatif (Biodiesel). Elkawnie: Journal of Islamic Science and Technology, 4(2), 151-164.

Hossain, A. B. M. S., \& Mazen, M. A. (2010). Effects of catalyst types and concentrations on biodiesel production from waste soybean oil biomass as renewable energy and environmental recycling process. Australian Journal of Crop Science, 4(7), 550-555.

Karasek, F. W., \& Clement, R. E. (2012). Basic gas chromatography-mass spectrometry: principles and techniques. Elsevier.

Ma, F., \& Hanna, M. A. (1999). Biodiesel production: a review. Bioresource Technology, 70(1), 1-15.

Majid, A. A., Prasetyo, D., \& Danarto, Y. C. (2012). Pembuatan biodiesel dari 
minyak jelantah dengan menggunakan iradiasi gelombang mikro.

Mastukik, D. (2006). Transesterifikasi minyak jelantah kelapa sawit menjadi Biodiesel menggunakan katalis $\mathrm{NaOH}$ tanpa proses esterifikasi dan katalis asam (H2SO4 dan Zeolit-Y) melalui proses esterifikasi. Universitas Gadjah Mada.

Muderawan, I. W., \& Daiwataningsih, N. K. P. (2016). Pembuatan Biodiesel Dari Minyak Nyamplung (Calophyllum Inophylum L.) dan Analisis Metil Esternya dengan GC-MS. Prosiding Seminar Nasional MIPA.

Ningtyas, D. P. (2013). Pengaruh Katalis Basa (NaOH) pada Tahap Reaksi Transesterifikasi terhadap Kualitas Biofuel dari Minyak Tepung Ikan Sardin. Jurnal Teknosains, 2(2).

Permana, E., Naswir, M., Sinaga, M. E. T., Alfairuz, A., \& Murti, S. D. S. (2020). Kualitas Biodiesel dari Minyak Jelantah Berdasarkan Proses Saponifikasi dan Tanpa Saponifikasi. JTT (Jurnal Teknologi Terapan), 6(1), 26-31.

Prasetyo, J. (2018). Studi Pemanfaatan Minyak Jelantah sebagai Bahan Baku Pembuatan Biodiesel. Jurnal IImiah Teknik Kimia, 2(2), 45-54.

Prastyo, H. S., Margaretha, Y. Y., \& Aning Ayucitra, S. (2011). Transesterifikasi Minyak Kelapa Sawit dengan Menggunakan Katalis Padat dari Cangkang Keong Mas (Pomacea sp.).

Setiawati, E., \& Edwar, F. (2012). Teknologi Pengolahan Biodiesel Dari Minyak Goreng Bekas dengan Teknik Mikrofiltrasi dan Transesterifikasi sebagai Alternatif Bahan Bakar Mesin Diesel. Riset Industri. 